Article

\title{
Employee Volunteering Meaningfulness and Organizational Citizenship Behavior: Exploring the Effects of Organizational Support, Pride, and Trust
}

\author{
Seunghee Im and Yang Woon Chung * \\ College of Economics and Business Administration, University of Suwon, 17 Wauan-gil, Bongdam-eup, \\ Hwaseong-si 18323, Gyeonggi-do, Korea; shim@suwon.ac.kr \\ * Correspondence: jywchung@suwon.ac.kr
}

Received: 29 October 2018; Accepted: 13 December 2018; Published: 18 December 2018

\begin{abstract}
This study examined the mediating effects of organizational pride and trust on the relationship between employee volunteering meaningfulness and organizational citizenship behavior. The study also investigated the moderating effects of perceived organizational support for the relationships between volunteering meaningfulness with organizational pride and trust. The study was administered in South Korea and sampled 267 full-time employees and found organizational pride and trust mediates the relationship between volunteering meaningfulness and organizational citizenship behavior, while perceived organizational support moderated the relationships between volunteering meaningfulness and organizational pride and trust. In addition, supplementary analysis found mediated moderation suggesting that supportive feelings had indirect effects on citizenship behavior.
\end{abstract}

Keywords: volunteering meaningfulness; organizationa pride; organizational trust; perceived organizational support; organization citizenship behavior

\section{Introduction}

Corporate social responsibility (CSR) is argued to be indispensable for sustainable business [1]. CSR is referred to as the discretionary business practices and contributions of organizational resources to positively affect social change and environmental sustainability [2,3]. Studies have suggested that CSR leads to corporate sustainable development, enabling companies to improve their profitability and create social values simultaneously (e.g., [4]). Moreover, CSR initiatives help companies create a trusting environment for innovation which enhances long-term competitive advantages that contributes to corporate sustainability [5].

Employee volunteering is one of the fastest growing CSR activities and an increasing number of organizations have developed CSR programs to support and organize opportunities for employees to volunteer their skills and time to help serve the community [6]. CSR programs are worldwide as over $90 \%$ of Fortune 500 companies operate employee volunteering programs and $80 \%$ of European organizations provide employee volunteering programs $[7,8]$. Corporate volunteering programs are also prevalent in Korea; a recent survey showed that $79 \%$ of the top 500 Korean companies operate employee volunteering programs and more than $50 \%$ of the employees have participated in the corporate volunteering programs [9]. Therefore, previous studies have suggested that employee volunteering has been one of the fastest growing areas of CSR activities worldwide [10].

Employee volunteering is important in that it can form partnerships with external stakeholders as a part of an organization's CSR actions to convey its corporate value [11]. Moreover, it is meaningful that corporate support for employee volunteering is considered as an important means by which 
companies can demonstrate their CSR initiatives [12]. In particular, the importance of employee volunteering is emphasized in that CSR strategies are most effective when employees become leading enactors while their employers act as supportive facilitators [13].

Due to the growing prevalence of employee volunteering, academic research on employee volunteering has flourished. This research stream has mainly aimed to emphasize the benefits of employee volunteering for both employees and organizations, showing that employee volunteering positively influences numerous organizational attitudes and behaviors [14-17]. Research has suggested that volunteering meaningfulness has a positive impact on behavioral outcomes $[18,19]$; however, despite prolific academic effort examining the organizational consequences of employee volunteering, relatively little is known about the underlying mechanisms and boundary conditions associating employee volunteering and outcomes (e.g., [20-22]). Recently, Rodell et al. [17] conceptualized an integrative framework delineating employee attitudes to mediate the relationships between employee volunteering and behavioral outcomes. The model suggested that workplace attitudes such as identification, pride, and job satisfaction can mediate the relationships between employee volunteering and work behaviors such as task performance, organizational citizenship behavior, and counterproductive work behavior. Moreover, Glavas [23] conceptualized model suggested that perceived organizational support (POS) can enhance the effects of employee volunteering on organizational outcomes such as job satisfaction, organizational identification, and organizational commitment. Therefore, based on their frameworks, this study empirically examined the mediating effects of organizational pride and trust for the relationship between volunteering meaningfulness and organizational citizenship behavior and the moderating effects of perceived organizational support for the relationships between volunteer meaningfulness and organizational pride and trust.

As there are limited studies on underlying mechanisms and boundary conditions that associate CSR and organizational outcomes, this study contributes by associating volunteer meaningfulness to organizational citizenship behavior via organizational pride and trust which examines beyond the direct effects of employee volunteering. In addition, the findings also contribute by explaining how perceived organizational support can further enhance the positive effects of volunteer meaningfulness to organizational pride and trust as well as indirectly affecting organizational citizenship behavior.

\section{Theoretical Background and Hypotheses Development}

\subsection{Corporate Sustainability and Employee Volunteering}

Corporate sustainability and CSR have been introduced to provide organizations with the necessary guidance for mutual benefits that enhance their long-term profitability and create social value [24]. Prior studies have suggested a positive relationship between CSR and corporate sustainability (e.g., [25]). Accordingly, organizations can be sustainable by continuously developing and implementing CSR activities and resulting in an effective integration of corporate profitability and social benefits that can create competitive advantage as well as enable the organization to maintain sustainable development [26].

Corporate sustainability can be attributed as fulfilling the needs of corporate stakeholders [27]. Employees are considered to be an essential factor that potentially affects corporate sustainability [28]. In this perspective, Grant [10] asserted the needs for employee-centered understanding of CSR and the importance of employee participation in corporate volunteering. Similarly, Lee and Chen [4] mentioned that organizations should consider employee volunteering as a long-term process for corporate sustainability.

Employee volunteering can be defined as individuals investing their time or skills for a planned activity aimed at an external group or organization [28]. This definition incorporates three core components. First, volunteering involves active giving activities instead of passive forms of support. Second, volunteering is a planned activity rather than a spontaneous act of helping [17,29]. 
Third, volunteering occurs within a volunteer group or organization $[17,30]$. Studies have found that employee volunteering significantly affects workplace attitudes such as job satisfaction, organizational identification, commitment, and turnover intentions and workplace behaviors such as task performance, organizational citizenship behavior, and teambuilding $[15,16,19,20,31]$. Thereby, extant studies found that employee volunteering can positively contribute to organizational performance.

Social exchange theory and social identity theory have been applied as key theoretical frameworks to how corporate volunteering is related to organizational outcomes [15]. According to social exchange theory, social exchange involves a series of interactions between two parties which then invokes a mutual obligation to reciprocate toward one another [32]. CSR can be explained by reciprocal relationships as organizations provide and promote good organizational practices toward the employees and employees reciprocate to the organization by perceiving positive workplace attitudes and engaging in positive organizational behaviors [33].

Social identity theory suggests that people tend to interpret their identities in a social environment. The theory focuses on social categorization in which people can define themselves in relations to a social group they want to be a part of. Previous studies have argued that an individual's social identity can be derived from one's organization, thereby creating a psychological connection between the individual and the organization [34]. CSR can communicate the organization's values that can significantly influence an employee's perception about one's organization. When an employee favorably perceives one's organization and prefers to be identified and affiliated with the organization, it then activates prosocial organizational attitudes and behaviors.

\subsection{Mediating Effects for the Relationship between Volunteering Meaningfulness and Organizational Citizenship Behavior}

The sense of meaningfulness derived from an activity is the most commonly mentioned reason for volunteering. It is a form of intrinsic motivation that guides subsequent behavior as people tend to volunteer in order to fulfill their desire to perceive significance and values in their lives [17]. Volunteering meaningfulness is an employee's understanding of the significance and purpose of one's volunteer work [35]. Employees feel meaningfulness from volunteering when they commit themselves to their affiliation with such work that gives them favorable status and recognition and respect from others [36].

Based on social identity theory, employees that participate in corporate volunteering and perceive meaningfulness from volunteering will tend to classify themselves with an organization as organizational members. As they identify with the organization, they will likely become integrated and congruent with the organization. Subsequently, organizational identification will regulate an individual's perceptions and behaviors within an organizational context [37]. In this regard, the relationship between volunteer meaningfulness and organizational pride can be explained by social identity theory as Pajo and Lee [38] demonstrated that opportunities to volunteer had an important role in promoting an employee's perceptions on one's prosocial organizational identity. Furthermore, volunteering meaningfulness provides employees with a strong sense of connection with their organization because organizational support of such activities is a basis of pride [39].

Prior literature suggests that organizational pride can be a psychological mechanism that can associate volunteering meaningfulness and organizational citizenship behavior [21,39]. When employees feel meaningfulness in their work, they are more likely to collaborate with their coworkers for the good of their organization. Additionally, they will be more likely to go beyond the boundaries of their job description and engage in citizenship behaviors [39,40]. Organizational citizenship behavior refers to voluntary, helpful, and constructive behaviors that are intended to benefit the organization or its members [18]. Organizational citizenship behavior can be directed toward individuals (OCBI) and the organization itself (OCBO). OCBI is defined as behaviors that benefit specific organizational members while OCBO are behaviors that benefit the organization in 
general [41]. The distinction between OCBI and OCBO is important as the two can have different predictors and outcomes [41,42].

Accordingly, employee volunteering engenders pride in the organization and provides employees with a rationale for engaging in organizational citizenship behavior. Rodell et al. [19] argued that positive feelings associated with corporate volunteering is shared among employees and organizational pride captures this shared affective experience among employees. Similarly, volunteers that perceived organizational pride increased the likelihood for individuals to engage in organizational citizenship behavior $[43,44]$. Based on these findings, we expect that volunteering meaningfulness will influence organization citizenship behavior by fostering a sense of organizational pride. Hence, we propose the following:

Hypothesis 1 (H1). Organizational pride will mediate the relationship between volunteering meaningfulness and OCBI.

Hypothesis 2 (H2). Organizational pride will mediate the relationship between volunteering meaningfulness and OCBO.

Organizational trust can be another mechanism that can associate the relationship between volunteering meaningfulness and organizational citizenship behavior. Recent CSR studies have argued that trust can be a relevant underlying mechanism that links CSR activities to workplace attitudes and behaviors $[45,46]$. Pivato et al. [47] argued that trust is an initial consequence of CSR and the direct result of certain CSR activities. Similarly, Choi and Yu [45] suggested that an employee's perceived trust can be a mediating mechanism that can associate CSR with organizational outcomes.

As shown, volunteering can provide employees with a sense of organizational identification that allows organizational members to positively perceive their organization. According to social identity theory, corporate citizenship may positively influence affection, attribution, retention, and motivation of employees because they strongly identify with positive organizational values [22]. In this regard, when organizational members perceive volunteering meaningfulness, they form affectionate bonds to their organizations which can result in positive workplace attitudes and behaviors such as organizational trust [48]. Furthermore, organizational members are likely to appreciate their organizations when there are opportunities for feelings of meaning, impact, and self-determination. Subsequently, they will be more likely to reciprocate by increased loyalty, commitment, and attachment to the organization [49]. As a result, studies have found volunteering to be positively related to workplace attitudes such as organizational identification [50] and organizational commitment [21]. Therefore, we posit the following:

Hypothesis 3 (H3). Organizational trust will mediate the relationship between volunteering meaningfulness and OCBI.

Hypothesis 4 (H4). Organizational trust will mediate the relationship between volunteering meaningfulness and OCBO.

\subsection{Moderating Effect of Perceived Organizational Support}

Organizational members are likely to perceive their organizations to have human-like characteristics [51] as they can differentiate positive and negative treatment from the organization in terms of how an organization values their contribution and cares about one's well-being. POS creates obligatory feelings toward one's organization's welfare and goals, thereby increasing individuals to become more committed, increase their work effort and work responsibilities while decreasing detrimental attitudes and behaviors toward the organization (e.g., [52]). In this regard, employees who perceive higher levels of organizational support are more likely to reciprocate toward the organization 
with high levels of emotional attachment [53]. In addition, Rich et al. [54] noted that supportive perceptions provide a psychological safe workplace environment so that an employee can be more engaged when an organization supports an employee.

Employees that positively perceive organizational support tend to have favorable perceptions about their organizations. In this regard, POS can moderate the relationships between volunteer meaningfulness with organizational pride and trust. POS will further strengthen the positive effects of volunteer meaningfulness on organizational pride and trust as POS can provide positive organizational indications to organizational members that further stimulate positive organizational attitudes. Thus, we propose the following:

Hypothesis 5 (H5). Perceived organizational support will moderate the relationship between volunteering meaningfulness and organizational pride, as higher levels of perceived organizational support will strengthen the relationship.

Hypothesis 6 (H6). Perceived organizational support will moderate the relationship between volunteering meaningfulness and organizational trust, as higher levels of perceived organizational support will strengthen the relationship.

The research model is depicted in Figure 1.

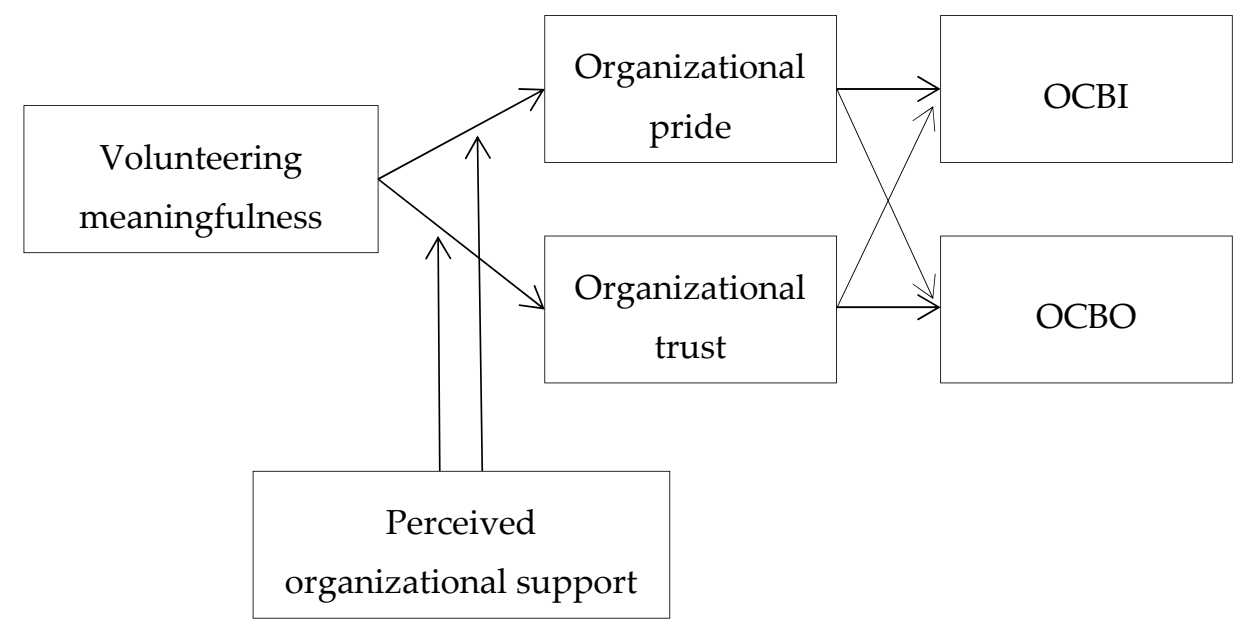

Figure 1. Research model.

\section{Method}

\subsection{Data Collection}

We collected data from full-time employees from four organizations using a self-administered questionnaire in South Korea. Organizations were selected based on whether they operated their own CSR activities and had numerous employee volunteer programs. The average annual total sales of the companies were 2.28 billion dollars ranging from 322.28 million dollars to 4.59 billion dollars. The average number of participating employees from the four organizations was 2619 employees and the range of participating employees ranged from 334 to 5611 employees [55]. The organizations operate a variety of corporate volunteering programs such as educational services for children from low income families, assistance programs for people with disabilities or living under hardship, and environmental awareness and conservation programs. The company provides information to the employees about volunteer activities, times, and locations. Employees are allowed to voluntarily choose their volunteer work without having a disadvantage when an employee does not participate in volunteering activities. 
The questionnaires were accompanied by a letter to the volunteering program managers and the survey was given in-person to each participant in an individually sealed envelope. The cover letter stated a concise purpose of the study and emphasized anonymity and confidentiality to control for social desirability bias. To further maintain anonymity, the questionnaire did not include any specific personal information that could identify the individual. Also, we assured that the data would be used for research purposes only.

Questionnaires were distributed to 400 employees and 285 questionnaires were returned (response rate: $71.25 \%$ ). Out of 285 questionnaires, 267 were usable due to missing data. The majority of the respondents was male (53.56\%), average age was 33.22 years, and average tenure was 8.45 years. A total of $81.65 \%$ had a college degree or higher, regarding organizational position, $59.18 \%$ were entry level employees and $40.82 \%$ were managers. A total of $19.10 \%$ had less than 2 years of volunteer experience while $41.20 \%$ had more than 5 years of experience.

\subsection{Measures}

As the study was administered in South Korea, the measures were translated in Korean by professional bilingual researchers and the translation were back-translated by another bilingual researcher to ensure the accuracy of the translations. Seven-point Likert scales (" 1 = strongly disagree"; "7 = strongly disagree") were used to measure all items.

Respondents were asked to evaluate volunteering meaningfulness with an adaptation of Spreitzer's [56] three-item scale. Sample items included: 'My volunteer activities are personally meaningful to me,' and 'The volunteer work I do is very important to me.' The reliability of this scale was 0.93 .

Perceived organizational support was measured with Coyle-Shapiro and Conway's [57] 7-item scale. Sample items include: 'The organizational values my contributions to its well-being,' and 'The organization is willing to help me when I need a special favor.' The reliability of this scale was 0.96 .

Organizational trust was measured with Cook and Wall's [58] 6-item scale. Sample items included: 'Management can be trusted to make sensible decisions for the company's future' and 'Management at work seems to do an efficient job." The reliability of this scale was 0.95 .

Organizational pride was measured with Jones' [21] 4-item scale. Sample items included: 'I am proud to work for my organization,' and 'I am proud to be associated with my organization.' The reliability of this scale was 0.96 .

OCBI was measured with Williams and Anderson's [41] 7-item scale. Sample items included: 'Takes a personal interest in other employees,' and 'Help others who have been absent.' The reliability of this scale was 0.91 .

OCBO was measured with Williams and Anderson's [41] 7-item scale. Sample items included: 'Gives advance notice when unable to come to work,' and 'Attendance at work is above the norm.' The reliability of this scale was 0.86 .

Gender, level of education, age, position, and organizational tenure were included as control variables for the analyses.

\section{Results}

Common method variance is a potential concern as questionnaires were self-reported. In order to control for common method variance, this study implemented procedural remedies by guaranteeing anonymity and confidentiality. In addition, Harman's single factor analysis was applied to check for possible common method variance. The results revealed that there was no dominant single factor explaining a majority of the variance, thus common method variance was not a considerable issue.

Table 1 presents the descriptive statistics and correlations among the variables. Confirmatory factor analysis (CFA) was conducted to examine the empirical distinction between the study variables. To evaluate the fit of the measurement model, normal fit index (NFI), Tucker-Lewis Index (TLI), comparative fit index (CFI), and root mean square error of approximation (RMSEA) 
were estimated. The results indicated an acceptable measurement model fit $\left(\chi^{2}(233)=436.75\right.$, $p<0.01$; NFI $=0.94, \mathrm{TLI}=0.97, \mathrm{CFI}=0.97, \mathrm{RMSEA}=0.06$ ). To confirm discriminant validity of the hypothesis model constructs, a one-factor model to the hypothesized six-factor model were compared. As presented in Table 2, the results showed that the six-factor model was a better fit compared to the other models.

All standardized factor loadings were significant $(p<0.01)$ with the lowest standardized loading equal to 0.71 . The composite reliability $(\mathrm{CR})$ coefficients exceeded the recommend value of 0.70 for all constructs $\left(\mathrm{CR}_{\mathrm{vm}}=0.82 ; \mathrm{CR}_{\text {pos }}=0.98 ; \mathrm{CR}_{\mathrm{op}}=0.95 ; \mathrm{CR}_{\text {tio }}=0.95 ; \mathrm{CR}_{\mathrm{ocbi}}=0.97 ; \mathrm{CR}_{\text {ocbo }}=0.93\right)$ and the average variance extracted (AVE) values for the constructs were all greater than the recommended value of $0.50\left(\mathrm{AVE}_{\mathrm{vm}}=0.87 ; \mathrm{AVE}_{\mathrm{pos}}=0.79 ; \mathrm{AVE}_{\mathrm{op}}=0.85 ; \mathrm{AVE}_{\mathrm{ot}}=0.83 ; \mathrm{AVE}_{\mathrm{ocbi}}=0.65 ; \mathrm{AVE}_{\mathrm{ocbo}}=0.71\right)$. In addition, the AVE values for each construct was higher than any squared correlation indicating satisfactory discriminant validity [59]. Thus, the research model's variables had sufficient reliability and validity.

Table 1. Descriptive statistics and correlations.

\begin{tabular}{|c|c|c|c|c|c|c|c|c|c|c|c|c|}
\hline & $\mathbf{M}$ & SD & 1 & 2 & 3 & 4 & 5 & 6 & 7 & 8 & 9 & 10 \\
\hline 1. Gender & 1.46 & 0.50 & 1.00 & & & & & & & & & \\
\hline 2. Education & 2.43 & 0.84 & $-0.48^{* *}$ & 1.00 & & & & & & & & \\
\hline 3. Age & 33.22 & 7.66 & $-0.38^{* *}$ & $0.28 * *$ & 1.00 & & & & & & & \\
\hline 5. Tenure & 8.45 & 6.91 & 0.05 & -0.05 & $0.76^{* *}$ & $0.38^{* *}$ & 1.00 & & & & & \\
\hline 6. VM & 5.12 & 1.02 & $-0.24^{* *}$ & $0.20 * *$ & 0.24 ** & 0.13 * & 0.11 & 1.00 & & & & \\
\hline 7. POS & 4.90 & 0.92 & -0.31 ** & 0.12 & 0.13 * & 0.08 & 0.00 & $0.57^{* *}$ & 1.00 & & & \\
\hline 8. OP & 5.31 & 0.91 & $-0.27^{* *}$ & 0.12 & $0.27^{* *}$ & $0.17^{* *}$ & 0.15 ** & 0.50 ** & 0.58 ** & 1.00 & & \\
\hline 11. ОСВО & 5.40 & 0.91 & $-0.22 * *$ & 0.12 & $0.31^{* *}$ & $0.15^{*}$ & $0.18 * *$ & $0.47^{* *}$ & $0.45^{* *}$ & $0.71 * *$ & $0.63^{* *}$ & $0.65^{* *}$ \\
\hline
\end{tabular}

VM: Volunteering meaningfulness; POS: Perceived organizational support; OP: Organizational pride; OT: Organizational trust, OCBI: Organizational citizenship behavior toward individuals; OCBO: Organizational citizenship behavior benefited the organization; ${ }^{*} p<0.05,{ }^{* *} p<0.01$.

Table 2. Confirmatory factor analysis results.

\begin{tabular}{ccccccc}
\hline & $\mathbf{X}^{\mathbf{2}}$ & $\mathbf{d f}$ & $\mathbf{N F I}$ & TLI & CFI & RMSEA \\
\hline One-factor model & 2713.99 & 249 & 0.62 & 0.61 & 0.65 & 0.19 \\
Two-factor model & 2489.48 & 248 & 0.66 & 0.64 & 0.68 & 0.18 \\
Three-factor model & 2213.55 & 246 & 0.69 & 0.68 & 0.72 & 0.17 \\
Four-factor model & 1324.66 & 243 & 0.82 & 0.82 & 0.84 & 0.13 \\
Five-factor model & 585.51 & 238 & 0.92 & 0.94 & 0.95 & 0.07 \\
Six-factor model & 436.75 & 233 & 0.94 & 0.97 & 0.97 & 0.06 \\
\hline
\end{tabular}

Bootstrapping tests were conducted to test the parallel multiple mediation model as recommended by Hayes [60]. Bootstrapping is a statistical method based on resampling processes with replacement for testing indirect effects [61]. The bootstrapping method was conducted with 5,000 samples at 95\% confidence intervals to assess multiple mediation. Hierarchical regression analyses were conducted for the moderating hypotheses. Gender, age, level of education, position, and organizational tenure were included for all of the analyses.

Hypothesis 1 predicted that organizational pride will mediate the relationship between volunteering meaningfulness and OCBI. Likewise, Hypothesis 2 posited the mediating effect of organizational pride on the relationship between volunteering meaningfulness and OCBO. Hypothesis 3 proposed the mediating effect of organizational trust on the relationship between volunteering meaningfulness and OCBI and Hypothesis 4 predicted that organizational trust will mediate the relationship between volunteering meaningfulness and OCBO.

Table 3 and Figure 2 shows the multiple mediation regression analysis results. As shown in Table 3 , volunteering meaningfulness was positively associated with organizational pride $(\beta=0.40, p<0.01)$ and organizational trust $(\beta=0.44, p<0.001)$. For organizational citizenship behavior, organizational pride 
was positively related to OCBI $(\beta=0.48, p<0.001)$ and OCBO $(\beta=0.49, p<0.001)$ and organizational trust was also positively related to OCBI $(\beta=0.14, p<0.05)$ and $\mathrm{OCBO}(\beta=0.17, p<0.05)$.

Table 4 shows the bootstrap results for the indirect effects. Results indicate that organizational pride mediated the relationships between volunteering and OCBI and OBCO. The bootstrap results in a bootstrapped $95 \% \mathrm{CI}$ around the indirect effects did not contain zero for OCBI $(95 \% \mathrm{CI}=(0.13,0.27))$ and OCBO $(95 \% \mathrm{CI}=(0.12,0.27))$. Also, the mediating effects of organizational trust were significant on OCBI and OCBO. The results showing a $95 \% \mathrm{CI}$ around the indirect effect did not contain zero for OCBI $(95 \% \mathrm{CI}=(0.01,0.11))$ and $\mathrm{OBCO}(95 \% \mathrm{CI}=(0.02,0.14))$. The results of the bootstrapping tests of the multiple mediation effects show that both organizational pride and trust mediated volunteering meaningfulness with OCBI and OCBO, thus Hypotheses 1-4 were supported.

Table 3. Multiple mediation regression analysis.

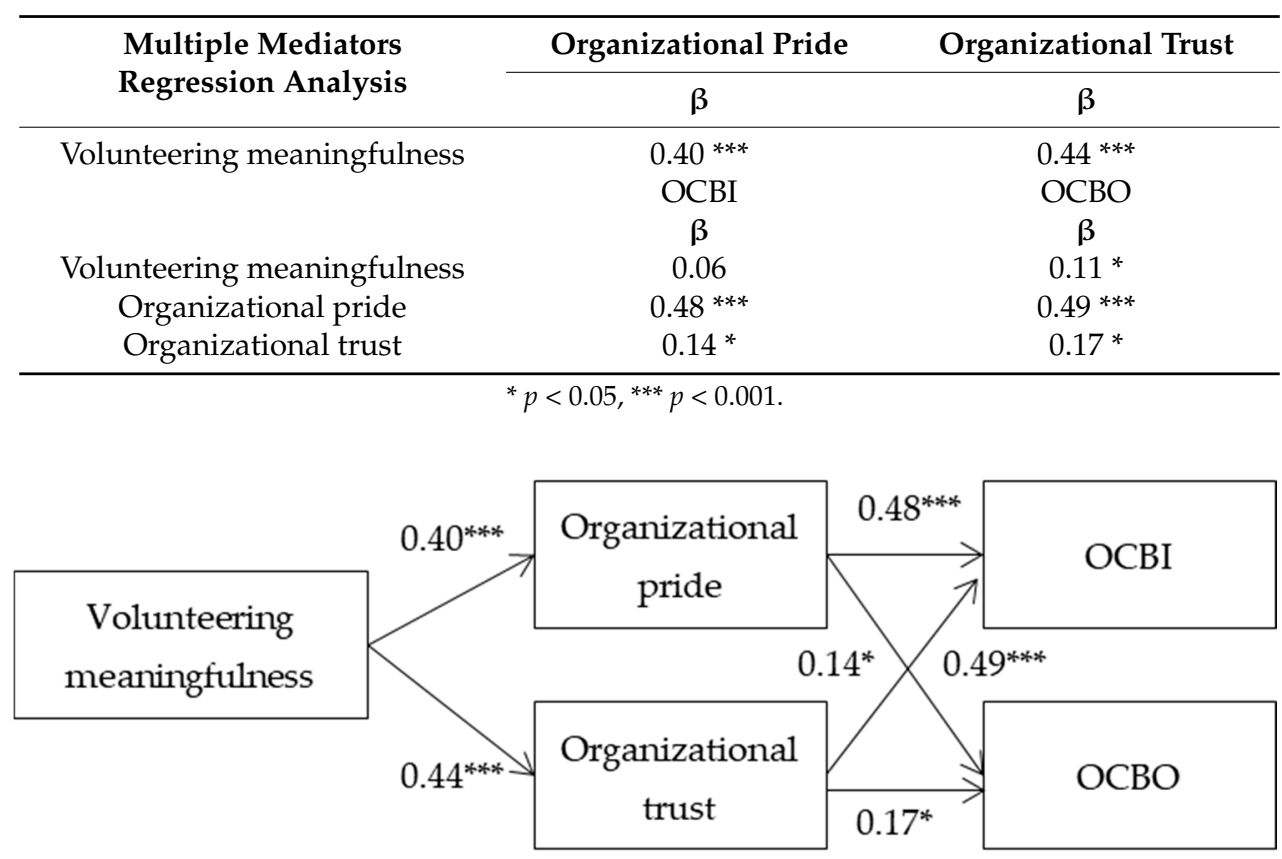

Figure 2. Estimates of the regression analysis. $\left({ }^{*} p<0.05,{ }^{* * *} p<0.001\right)$.

Table 4. Bootstrap results for indirect effects.

\begin{tabular}{ccccc}
\hline \multicolumn{5}{c}{ Bootstrapping Percentile 95 per cent CI } \\
\hline $\begin{array}{c}\text { Indirect effects on OCBI } \\
\text { Indirect effects }\end{array}$ & $\mathrm{M}$ & $\mathrm{SE}$ & $\mathrm{LL}:$ 95\%CI & UL: 95\%CI \\
Organizational pride & 0.19 & 0.04 & 0.13 & 0.27 \\
Organizational trust & 0.06 & 0.02 & 0.01 & 0.11 \\
Total & 0.25 & 0.04 & 0.18 & 0.34 \\
\hline Indirect effects on OCBO & & & & \\
$\quad$ Indirect effects & & & & \\
Organizational pride & 0.19 & 0.04 & 0.12 & 0.27 \\
Organizational trust & 0.07 & 0.03 & 0.02 & 0.14 \\
Total & 0.27 & 0.04 & 0.19 & 0.36 \\
\hline
\end{tabular}

Table 5 shows the hierarchical regression results for the moderating effects of perceived organizational support. In the regression model, variables were mean-centered to avoid potential multicollinearity [62]. Hypothesis 5 predicted that perceived organizational support will moderate the relationship between volunteering meaningfulness and organizational pride. Specifically, we posited that the relationship between volunteering meaningfulness and organizational pride becomes stronger 
when perceived organizational support increases. The results show that the moderating effect of organizational support between volunteering meaningfulness and organizational pride was significant $(\beta=0.11, p<0.05)$.

Hypothesis 6 posited that the relationship between volunteering meaningfulness and organizational trust becomes stronger as perceived organizational support increases. As shown in Table 5 , there was a significant interaction effect between volunteering meaningfulness and perceived organizational support on organizational trust $(\beta=0.09, p<0.05)$.

Table 5. Hierarchical regression model.

\begin{tabular}{|c|c|c|c|c|c|c|}
\hline \multirow[b]{2}{*}{ Variables } & \multicolumn{3}{|c|}{ Organizational Pride } & \multicolumn{3}{|c|}{ Organizational Trust } \\
\hline & Step 1 & Step 2 & Step 3 & Step 1 & Stpe 2 & Step 3 \\
\hline Gender & $-0.38^{* *}$ & $-0.27 *$ & -0.07 & $-0.44^{* *}$ & -0.33 * & -0.06 \\
\hline Education & -0.04 & -0.08 & -0.04 & -0.06 & -0.11 & -0.05 \\
\hline Age & 0.02 & 0.01 & 0.02 & 0.03 & 0.02 & $0.02 *$ \\
\hline Position & 0.01 & 0.02 & 0.02 & -0.03 & -0.02 & -0.02 \\
\hline Tenure & 0.00 & 0.00 & 0.00 & -0.01 & -0.01 & -0.01 \\
\hline Volunteering meaningfulness (VM) & & $0.40^{* * *}$ & $0.22 * * *$ & & $0.44^{* * *}$ & $0.19^{* * *}$ \\
\hline Perceived organizational support (POS) & & & $0.41^{* * *}$ & & & $0.54^{* * *}$ \\
\hline $\mathrm{VPM} \times \mathrm{POS}$ & & & $0.11 *$ & & & $0.09 *$ \\
\hline$R^{2}$ & 0.11 & 0.29 & 0.42 & 0.11 & 0.31 & 0.52 \\
\hline$\Delta R^{2}$ & 0.11 & 0.18 & 0.14 & 0.11 & 0.21 & 0.20 \\
\hline$\Delta \mathrm{F}$ & $6.25^{* * *}$ & $65.94^{* * *}$ & $30.72 * * *$ & $6.43^{* * *}$ & $78.08^{* * *}$ & $54.3^{* * *}$ \\
\hline$F$ & $6.25^{* * *}$ & $17.49^{* * *}$ & $23.79^{* * *}$ & $6.43^{* * *}$ & $19.95^{* * *}$ & $34.65^{* * *}$ \\
\hline
\end{tabular}

We further depicted the interaction effects at one standard deviation above and below the mean [53]. As depicted in Figure 3, the positive relationship between volunteering meaningfulness and organizational pride was stronger when employees perceived more organizational support than when they perceived less organizational support. Similarly, Figure 4 shows employees that perceived higher levels of organizational support reported higher trust than those who perceived less organizational support. Thus, these results support Hypotheses 5 and 6.

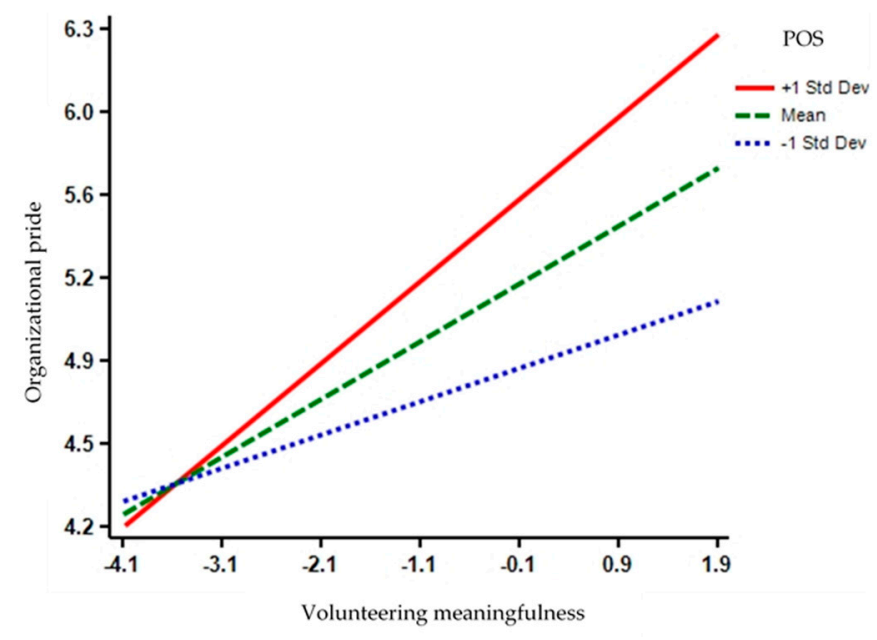

Figure 3. Moderating effects of perceived organizational support on volunteering meaningfulness and organizational pride. 


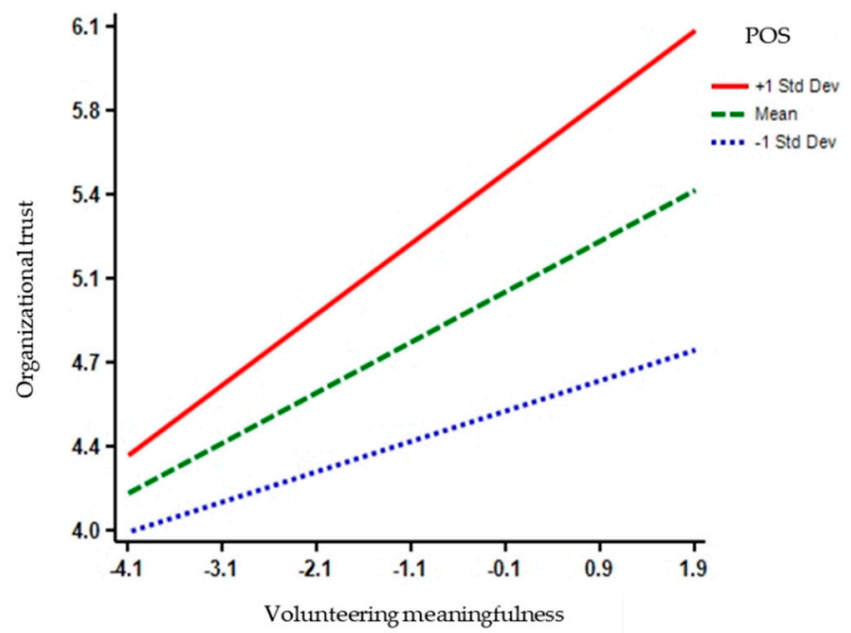

Figure 4. Moderating effects of perceived organizational support on volunteering meaningfulness and organizational trust.

We conducted additional analyses to test for the mediated moderation models that further assess the robustness of our results. Following the procedures by Muller, Judd, and Yzerbyt [63], Table 6 presents the results of mediated moderation analysis for organizational pride. As shown in Table 6, Equation 1 had significant interaction effects on the relationship between volunteering meaningfulness and OCBI $(\beta=0.14, p<0.01)$ and the relationship between volunteering meaningfulness and OCBO $(\beta=0.09, p<0.05)$. In Equation 2 , results showed that the interaction effect on the relationship between volunteering meaningfulness and organizational pride was significant $(\beta=0.11, p<0.05)$. In Equation 3, organizational pride had a significant effect on both OCBI and OCBO $(\beta=0.54, p<0.001$; $\beta=0.60, p<0.001$, respectively). Equation 3 indicated that the interaction effect between volunteering meaningfulness and perceived organization support on OCBI was reduced $(\beta=0.08, p<0.05)$, and the interaction effect between volunteering meaningfulness and perceived organization support on OCBO was not significant $(\beta=0.00, p>0.1)$. These findings suggest that individuals that perceived that volunteering was meaningful and felt support from the organization were more likely to have feelings of organizational pride, which then further increased their citizenship behavior.

Table 6. Regression results for mediated moderation model: Organizational pride.

\begin{tabular}{|c|c|c|c|c|c|c|}
\hline \multirow{2}{*}{ Variables } & \multicolumn{3}{|c|}{ OCBI } & \multicolumn{3}{|c|}{ ОСВО } \\
\hline & $\begin{array}{l}\text { Eq. 1: } \\
\text { OCBI }\end{array}$ & $\begin{array}{c}\text { Eq. 2: } \\
\text { OP }\end{array}$ & $\begin{array}{l}\text { Eq. 3: } \\
\text { OCBI }\end{array}$ & $\begin{array}{l}\text { Eq. 1: } \\
\text { OCBO }\end{array}$ & $\begin{array}{c}\text { Eq. 2: } \\
\text { OP }\end{array}$ & $\begin{array}{l}\text { Eq. 3: } \\
\text { OCBO }\end{array}$ \\
\hline Gender & 0.17 & -0.07 & $0.21 *$ & 0.04 & -0.07 & 0.08 \\
\hline Age & 0.02 & 0.02 & 0.01 & $0.04 *$ & 0.02 & $0.03 *$ \\
\hline Education & 0.02 & -0.04 & 0.04 & -0.05 & -0.04 & -0.03 \\
\hline Position & -0.70 & 0.02 & $-0.08 *$ & -0.02 & 0.02 & -0.01 \\
\hline Tenure & 0.00 & 0.00 & -0.00 & -0.01 & 0.00 & -0.01 \\
\hline Volunteering meaningfulness (VM) & $0.22 * * *$ & $0.22 * * *$ & $0.10^{*}$ & $0.27^{* * *}$ & $0.22 * * *$ & $0.14^{* *}$ \\
\hline Perceived organizational support (POS) & $0.26^{* *}$ & $0.41^{* * *}$ & $0.04 *$ & $0.25^{* * *}$ & $0.41^{* * *}$ & -0.00 \\
\hline $\mathrm{VM} \times \mathrm{POS}$ & $0.14^{* *}$ & $0.11 *$ & $0.08 *$ & $0.09 *$ & $0.11 *$ & 0.00 \\
\hline Organizational pride (OP) & & & $0.54^{* * *}$ & & & $0.60^{* * *}$ \\
\hline $\mathrm{OP} \times \mathrm{POS}$ & & & -0.01 & & & 0.04 \\
\hline $\mathrm{R}^{2}$ & 0.32 & 0.42 & 0.55 & 0.33 & 0.42 & 0.54 \\
\hline $\mathrm{F}$ & $15.18^{* * *}$ & $23.79 * * *$ & $30.76^{* * *}$ & $16.08^{* * *}$ & $23.79 * * *$ & $29.77^{* * *}$ \\
\hline
\end{tabular}

As seen in Table 7, Equation 1 showed significant moderation effects on the relationship between volunteering meaningfulness and OCBI $(\beta=0.14, p<0.01)$ and the relationship between volunteering meaningfulness and $\mathrm{OCBO}(\beta=0.09, p<0.05)$. In Equation 2 , the interaction effect was significant on the relationship between volunteering meaningfulness and organizational trust 
( $\beta=0.09, p<0.05$ ). Equation 3 showed that organizational trust had a significant effect on both OCBI and OCBO ( $\beta=0.40, p<0.001 ; \beta=0.48, p<0.001$, respectively). In Equation 3, the moderating effect of perceived organizational support was reduced on the association between volunteering meaningfulness and OCBI $(\beta=0.14, p<0.01)$. Equation 3 also indicated that the moderating effect of organizational trust on the association between volunteering meaningfulness and OCBO was not significant $(\beta=0.06, p>0.10)$. Similar to perceptions of organizational pride, these findings also suggest that volunteer meaningfulness and perceived organizational support increased an individual's feelings of organizational trust, which then promoted their citizenship behavior.

Table 7. Regression results for mediated moderation model: Organizational trust.

\begin{tabular}{ccccccc}
\hline \multirow{2}{*}{ Variables } & \multicolumn{3}{c}{ OCBI } & \multicolumn{3}{c}{ OCBO } \\
& Eq. 1: & Eq. 2: & Eq. 3: & Eq. 1: & Eq. 2: & Eq. 3: \\
& OCBI & OT & OCBI & OCBO & OT & OCBO \\
\hline Gender & 0.17 & -0.06 & 0.20 & 0.04 & -0.06 & 0.07 \\
Age & 0.02 & $0.03^{*}$ & 0.01 & $0.04^{*}$ & $0.03^{*}$ & $0.02^{*}$ \\
Education & 0.02 & -0.05 & 0.04 & -0.05 & -0.05 & -0.02 \\
Position & -0.70 & -0.02 & -0.06 & -0.02 & -0.02 & -0.01 \\
Tenure & 0.00 & -0.01 & 0.00 & -0.01 & -0.01 & -0.01 \\
Volunteering Meaningfulness (VM) & $0.22^{* * *}$ & $0.19^{* * *}$ & $0.14^{*}$ & $0.27^{* * *}$ & $0.19^{* * *}$ & $0.18^{* *}$ \\
Perceived organizational support (POS) & $0.26^{* *}$ & $0.54^{* * *}$ & 0.05 & $0.25^{* * *}$ & $0.54^{* * *}$ & -0.01 \\
VM $\times$ POS & $0.14^{* *}$ & $0.09^{*}$ & $0.14^{*}$ & $0.09^{*}$ & $0.09^{*}$ & 0.06 \\
Organizational trust (OT) & & & $0.40^{* * *}$ & & & $0.48^{* * *}$ \\
OT $\times$ POS & & & -0.07 & & -0.02 \\
$\mathrm{R}^{2}$ & 0.32 & 0.52 & 0.44 & 0.33 & 0.52 & 0.45 \\
F & $15.18^{* * *}$ & $34.65^{* * *}$ & 19.76 & $16.08^{* * *}$ & $34.65^{* * *}$ & $21.14^{* * *}$ \\
\hline
\end{tabular}

\section{Discussion}

The current study aimed to identify the multiple mediating effects of organizational pride and trust on the relationship between employee volunteering meaningfulness and organizational citizenship behavior. The study also investigated the moderating effects of perceived organizational support on the relationships between volunteering meaningfulness and organizational pride and trust. According to social identification, an individual will perceive oneness with or belongingness to the organization that one identifies with [34]. When an individual knows that one belongs to a certain group, it creates some emotional and value significance for group membership [64]; therefore, supporting the study results as both organizational pride and trust mediated the relationship between volunteering meaningfulness and organizational citizenship behavior. Employee volunteering enables employees to perceive volunteering meaningfulness which increases organizational pride and trust which then positively affects organizational citizenship behavior. The study also found perceived organizational support to moderate the relationships between volunteering meaningfulness and organizational pride and trust. These findings suggest that perceived organizational support further strengthens the relationships between volunteering meaningfulness and organizational outcomes and that organizational support plays a pertinent role in increasing the two mediating variables through employee volunteering.

This study has several theoretical implications as it supports and confirms the conceptualized models of Rodell et al. [17] and Glavas [23]. Prior research has mainly focused on the direct effects between employee volunteering and organizational outcomes (e.g., [14,65]) and studies have been limited on further explaining the relationships through underlying mechanisms (e.g., $[20,21])$. In this regard, this study broadens our knowledge in CSR research by providing empirical evidence on the mediating effects that further explain the link between volunteering meaningfulness and organizational citizenship behavior. In addition, the study findings support the boundary conditions on the impact of employee volunteering by demonstrating the moderating effects of perceived organizational support on the relationships between volunteering meaningfulness and organizational pride and trust. In addition, it is noteworthy that our findings demonstrated mediated moderation explaining that 
perceived organizational support can also indirectly affect organizational citizenship behavior through organizational pride and trust.

Moreover, the study findings showed the positive impact of corporate volunteering on organizational citizenship behaviors. Prior studies have claimed that it is crucial for organizational members to perceive positive workplace attitudes and engage in positive workplace behaviors to achieve organizational sustainability since employee are key stakeholders to organizational success (e.g., [66]). In this perspective, organizational citizenship behavior has been argued to be able to improve an organization's overall sustainability [67]. Therefore, the study extends CSR literature as it suggests that employee volunteering can result in organizational citizenship behaviors which then can improve corporate sustainability.

This study also has several practical implications. First, our findings suggest valuable insight in that it can help organizations and managers formulate an effective CSR strategy through employee volunteering. Managers might be skeptical about employee volunteering and worry that volunteering activities take employees away from their workplace [29] and that they may become more cynical about CSR perceptions than non-managers [68]. However, the study findings suggest that employee volunteering can lead to improved organizational outcomes that is, employee volunteering can support organizational values by carrying out CSR practices effectively. Second, corporate volunteering programs might be positively related to organizational performance when employees perceive volunteering to be meaningful. To elaborate, volunteering meaningfulness can help employees sustain motivation to continuously engage their volunteering activities [36]. Consequently, managers need to pay close attention to foster employee meaningfulness from the volunteering activities to ensure the enhancement of organizational outcomes.

As with any study, our study has some limitations. First, the study was conducted with a cross-sectional design making it difficult to formally draw inferences on the causal relationship. Thus, we did not completely rule out the possibility of a reverse causal relationship although there was theoretical explanation and conceptual frameworks to presume the hypothesized causal direction was appropriate. Therefore, future research should conduct a longitudinal approach which can provide a stronger argument for the causal relationship between volunteering and organizational outcomes. In addition, endogeneity might be a potential concern as variables are typically endogenous and the causal relationships are complex in survey-based empirical research [69]. Therefore, studies should apply econometric remedies that mitigate endogeneity such as the Generalized Method of Moments (GMM), fixed effect models, lagged independent and instrumental variables, as well as the addition of more meaningful control variables [70].

Second, the findings of the study cannot be generalized to other cultures as this study was conducted in South Korea. Employee volunteering programs and employee responses are significantly influenced by cultural contexts and culture is an important factor to be considered when operating corporate volunteering programs [71]. Thus, it is needed to replicate the study findings in other cultural contexts in order to further validate our findings.

Third, we did not consider individual differences in the study. Specifically, previous studies have emphasized personality is an important facet influencing specific behaviors. For example, studies argued that prosocial personality, agreeableness, efficacy have important relationships with volunteering (e.g., [72,73]). Organizational behavior literature found significant relationships between personality and organizational outcomes (e.g., [74,75]). Therefore, it would be fruitful to further explore the relationships between personality and employee volunteering.

Last, the study did not include organizational characteristics within the study model as we conducted our analysis at the individual level. However, it should be noted that organizational characteristics can be an important aspect within CSR studies. For instance, company size is an organizational characteristic [76] that can significantly affect employee volunteering [11]. Hence, future studies should also consider including organizational characteristics that can influence employee volunteering and organizational outcomes. 


\section{Conclusions}

Employee volunteering is one of the fastest growing CSR activities and the importance of corporate volunteering for corporate sustainability has been shown. Although there have been a number of research endeavors in this field, previous studies have not comprehensively explained psychological mechanisms and boundary conditions that associate CSR and organizational outcomes. Therefore, this study examined the mediating and moderating effects that link employee volunteering and organizational outcomes. The study found that organizational pride and trust mediated the relationship between volunteering meaningfulness and organizational citizenship behavior. In addition, results showed that perceived organizational support moderated the relationships between volunteering meaningfulness and organizational pride and trust. This study contributes to expand extant literature by associating volunteer meaningfulness to organizational citizenship behavior through organizational pride and trust. Moreover, the findings also contribute by elucidating how perceived organizational support can enhance the positive effects of volunteer meaningfulness to organizational pride and trust.

Author Contributions: S.I. and Y.W.C. developed the idea of the paper. S.I. analyzed the data and Y.W.C. reviewed prior studies. All authors wrote and approved the final manuscript.

Funding: This research received no external funding.

Conflicts of Interest: The authors declare no conflict of interest.

\section{References}

1. Yoo, D.; Lee, J. The effects of corporate social responsibility (CSR) fit and CSR consistency on company evaluation: The role of CSR support. Sustainability 2018, 10, 2956. [CrossRef]

2. Kotler, P.; Lee, N. Corporate Social Responsibility: Doing the Most Good for Your Company and Your Cause; John Wiley \& Sons: Hoboken, NJ, USA, 2005; ISBN 978-0-471-47611-5.

3. Samuel, O.; Wolf, P.; Schilling, A. Corporate volunteering: Benefits and challenges for nonprofits. Nonprofit Manag. Leadersh. 2013, 24, 163-180. [CrossRef]

4. Lee, L.; Chen, L. Boosting employee retention through CSR: A configurational analysis. Corp. Soc. Res. Environ. Manag. 2018, 25, 948-960. [CrossRef]

5. Wagner, M. Corporate social performance and innovation with high social benefits: A quantitative analysis. J. Bus. Ethics 2010, 94, 581-594. [CrossRef]

6. Plewa, C.; Conduit, J.; Quester, P.G.; Johnson, C. The impact of corporate volunteering on CSR image: A consumer perspective. J. Bus. Ethics 2015, 127, 643-659. [CrossRef]

7. Points of Light Institute, Standards for Employee Volunteer Program Developed. Available online: http:// www.csrwire.com/press_releases/16763-Standards-for-Employee-Volunteer-Programs-Developed (accessed on 3 September 2018).

8. Perez, M.J.; Poyatos, J.A.; Bosioc, D.; Civico, G.; Kahn, K.; Loro, S. Employee Volunteering and Employee Volunteering in Humanitarian ADI in Europe. 2014. Available online: http://ec.europa.eu/ echo/files/euaidvolunteers/EUAV_Study_Employee_Volunteering_Europe_FINAL_en.pdf (accessed on 30 November 2018).

9. The Federation of Korean Industries, Social Contribution White Paper. 2018. Available online: http:/ /www.fki.or.kr (accessed on 30 November 2018).

10. Grant, A.M.; Dutton, J.E.; Rosso, B.D. Giving commitment: Employee support programs and the prosocial sensemaking process. Acad. Manag. J. 2008, 51, 898-918. [CrossRef]

11. Basil, D.; Runte, M.; Basil, M.; Usher, J. Company support for employee volunteerism: Does size matter? J. Bus. Res. 2011, 64, 61-66. [CrossRef]

12. Collier, J.; Esteban, R. Corporate social responsibility and employee commitment. Bus. Ethics 2007, 16, 19-33. [CrossRef]

13. Jiang, H. Bridging Corporate Social Responsibility and Employee Communication. 2017. Available online: https://instituteforpr.org/bridging-corporate-social-responsibility-employee-communication (accessed on 30 November 2018). 
14. Breitsohl, H.; Ehrig, N. Commitment through Employee Volunteering: Accounting for the Motives of Inter-Organisational Volunteers. Appl. Psychol. 2017, 66, 260-289. [CrossRef]

15. Gatignon-Turnau, A.L.; Mignonac, K. (Mis)Using employee volunteering for public relations: Implications for corporate volunteers' organizational commitment. J. Bus. Res. 2015, 68, 7-18. [CrossRef]

16. Im, S.; Chung, Y.W.; Yang, J.Y. Employees' participation in corporate social responsibility and organizational outcomes: The moderating role of person-CSR fit. Sustainability 2017, 9, 28. [CrossRef]

17. Rodell, J.B.; Breitsohl, H.; Schröder, M.; Keating, D.J. Employee volunteering: A review and framework for future research. J. Manag. 2016, 42, 55-84. [CrossRef]

18. Peloza, J.; Hudson, S.; Hassay, D.N. The marketing of employee volunteerism. J. Bus. Ethics 2009, 85, 371-386. [CrossRef]

19. Rodell, J.B.; Booth, J.E.; Lynch, J.; Zipay, K. Corporate volunteering climate: Mobilizing employee passion for societal causes and inspiring future charitable action. Acad. Manag. J. 2017, 60, 1662-1681. [CrossRef]

20. Hu, J.; Jiang, K.; Mo, S.; Chen, H.; Shi, J. The motivational antecedents and performance consequences of corporate volunteering: When do employees volunteer and when does volunteering help versus harm work performance? Organ. Behav. Hum. Decis. Process. 2016, 137, 99-111. [CrossRef]

21. Jones, D.A. Does serving the community also serve the company? Using organizational identification and social exchange theories to understand employee responses to a volunteerism programme. J. Occup. Organ. Psychol. 2010, 83, 857-878. [CrossRef]

22. Peterson, D.K. The relationship between perceptions of corporate citizenship and organizational commitment. Bus. Soc. 2004, 43, 296-319. [CrossRef]

23. Glavas, A. Corporate social responsibility and employee engagement: Enabling employees to employ more of their whole selves at work. Front. Psychol. 2016, 31, 796. [CrossRef] [PubMed]

24. Ashrafi, M.; Adams, M.; Walker, R.; Magnan, G. How corporate social responsibility can be integrated into corporate sustainability: A theoretical review of their relationships. Int. J. Sustain. Dev. World Ecol. 2018, 25, 672-682. [CrossRef]

25. Bansal, T.; Song, H. Similar but not the same: Differentiating corporate sustainability from corporate responsibility. Acad. Manag. Ann. 2017, 11, 105-149. [CrossRef]

26. Hur, W.; Kim, H.; Woo, J. How CSR leads to corporate brand equity: Mediating mechanisms of corporate brand credibility and reputation. J. Bus Ethics 2014, 125, 75-86. [CrossRef]

27. Dyllick, T.; Hockerts, K. Beyond the business case for corporate sustainability. Bus. Strateg. Environ. 2002, 11, 130-141. [CrossRef]

28. Saratun, M. Performance management to enhance employee engagement for corporate sustainability. Asia-Pac. J. Bus. Admin. 2016, 8, 84-102. [CrossRef]

29. Wilson, J. Volunteering. Annu. Rev. Sociol. 2000, 26, 215-240. [CrossRef]

30. Musick, M.A.; Wilson, J. Volunteers: A Social Profile; Indiana University Press: Bloomington, IN, USA, 2008; ISBN 978-0-253-34929-3.

31. De Gilder, D.; Schuyt, T.N.M.; Breedijk, M. Effects of an employee volunteering program on the work force: The ABN-AMRO case. J. Bus. Ethics 2005, 61, 143-152. [CrossRef]

32. Cropanzano, R.; Mitchell, M.S. Social exchange theory: An interdisciplinary review. J. Manag. 2005, 31, 874-900. [CrossRef]

33. De Roeck, K.; Maon, F. Building the theoretical puzzle of employees' reactions to corporate social responsibility: An integrative conceptual framework and research agenda. J. Bus. Ethics 2018, 149, 609-625. [CrossRef]

34. Ashforth, B.E.; Mael, F. Social identity theory and the organization. Acad. Manag. Rev. 1989, 14, 20-39. [CrossRef]

35. Wrzesniewski, A.; Dutton, J.E. Crafing a job: Revisioning employees as active crafters of their work. Acad. Manag. Rev. 2001, 26, 179-201. [CrossRef]

36. Yim, F.; Fock, H. Social responsibility climate as a double-edged sword: How employee-perceived social responsibility climate shapes the meaning of their voluntary work? J. Bus. Ethics 2013, 114, 665-674. [CrossRef]

37. Hogg, M.A.; Terry, D.J.; White, K.M. A tale of two theories: A critical comparison of identity theory with social identity theory. Soc. Psychol. Q. 1995, 58, 255-269. [CrossRef] 
38. Pajo, K.; Lee, L. Corporate-sponsored volunteering: A work design perspective. J. Bus. Ethics 2011, 99, 467-482. [CrossRef]

39. Rodell, J.B. Finding meaning through volunteering: Why do employees volunteer and what does it mean for their jobs? Acad. Manag. J. 2013, 56, 1274-1294. [CrossRef]

40. Kahn, W.A. To be fully there: Psychological presence at work. Hum. Relat. 1992, 45, 321-349. [CrossRef]

41. Williams, L.J.; Anderson, S.E. Job satisfaction and organizational commitment as predictors of organizational citizenship and in-role behaviors. J. Manag. 1991, 17, 601-617. [CrossRef]

42. Podsakoff, N.P.; Whiting, S.W.; Podsakoff, P.M.; Blume, B.D. Individual and organizational level consequences of organizational citizenship behaviors. J. Appl. Psychol. 2009, 94, 122-141. [CrossRef] [PubMed]

43. Andreoni, J. Impure altruism and donations to public goods: A theory of warm-glow giving. Econ. J. 1990, 100, 464-477. [CrossRef]

44. Peloza, J.; Hassay, D.N. Intra-organizational volunteerism: Good soldiers, good deeds and good politics. J. Bus. Ethics 2006, 64, 357-379. [CrossRef]

45. Choi, Y.; Yu, Y. The influence of perceived corporate sustainability practices on employees and organizational performance. Sustainability 2014, 348-364. [CrossRef]

46. Hansen, S.D.; Dunford, B.B.; Boss, A.D.; Boss, R.W.; Angermeier, I. Corporate social responsibility and the benefits of employee trust: A cross-disciplinary perspective. J. Bus. Ethics 2011, 102, 29-45. [CrossRef]

47. Pivato, S.; Misani, N.; Tencati, A. The impact of corporate social responsibility on consumer trust: The case of organic food. Bus. Ethics Eur. Rev. 2008, 17, 3-12. [CrossRef]

48. Lin, C. Modeling corporate citizenship, organizational trust, and work engagement based on attachment theory. J. Bus. Ethics 2010, 94, 517-531. [CrossRef]

49. Liden, R.C.; Wayne, S.J.; Sparrowe, R.T. An examination of the mediating role of psychological empowerment on the relations between the job, interpersonal relationships, and work outcomes. J. Appl. Psychol. 2000, 85, 407-416. [CrossRef] [PubMed]

50. Bartel, C.A. Social comparisons in boundary-spanning work: Effects of community outreach on members' organizational identity and identification. Adm. Sci. Q. 2001, 46, 379-413. [CrossRef]

51. Eisenberger, R.; Huntington, R.; Hutchison, S.; Sowa, D. Perceived organizational support. J. Appl. Psychol. 1986, 71, 500-507. [CrossRef]

52. Rhoades, L.; Eisenberger, R. Perceived organizational support: A review of the literature. J. Appl. Psychol. 2002, 87, 698-714. [CrossRef] [PubMed]

53. Eisenberger, R.; Armeli, S.; Rexwinkel, B.; Lynch, P.D.; Rhoades, L. Reciprocation of perceived organizational support. J. Appl. Psychol. 2001, 86, 42-51. [CrossRef] [PubMed]

54. Rich, B.L.; LePine, J.A.; Crawford, E.R. Job engagement: Antecedents and effects on job performance. Acad. Manag. J. 2010, 53, 617-635. [CrossRef]

55. Fair Trade Commission, Corporate Information Disclosure of 2017. Available online: http:/ / groupopni.ftc. go.kr/ogroup/index.jsp (accessed on 20 November 2018).

56. Spreitzer, G.M. Psychological empowerment in the workplace: Dimensions, measurement, and validation. Acad. Manag. J. 1995, 38, 1442-1465. [CrossRef]

57. Coyle-Shapiro, J.A.M.; Conway, N. Exchange relationships: Examining psychological contracts and perceived organizational support. J. Appl. Psychol. 2005, 90, 774-781. [CrossRef] [PubMed]

58. Cook, J.; Wall, T. New work attitude measures of trust, organizational commitment and personal need non-fulfilment. J. Occup. Psychol. 1980, 53, 39-52. [CrossRef]

59. Fornell, C.; Larcker, D.F. Evaluating structural equation models with unobservable variables and measurement error. J. Mark. Res. 1981, 18, 39-50. [CrossRef]

60. Hayes, A.H. Introduction to Mediation, Moderation, and Conditional Process Analysis: A Regression-Based Approach; Guilford: New York, NY, USA, 2013; ISBN 978-1609182304.

61. Preacher, K.J.; Hayes, A.F. SPSS and SAS procedures for estimating indirect effects in simple mediation models. Behav. Res. Methods Instrum. Comput. 2004, 36, 717-731. [CrossRef] [PubMed]

62. Aiken, L.S.; West, S.G. Multiple Regression: Testing and Interpreting Interactions; SAGE: Newbury Park, CA, USA, 1991.

63. Muller, D.; Judd, C.M.; Yzerbyt, V.Y. When moderation is mediated and mediation is moderated. J. Pers. Soc. Psychol. 2005, 89, 852-863. [CrossRef] [PubMed] 
64. Tajfel, H.; Turner, J.C. An integrative theory of intergroup conflict. In The Social Psychology of Intergroup Relations; Austin, W.G., Worchel, S., Eds.; Brooks-Cole: Monterey, CA, USA, 1979.

65. Donia, M.B.L.; Sirsly, C.A.T.; Ronen, S. Employee attributions of corporate social responsibility as substantive or symbolic: Validation of a measure. Appl. Psychol. 2017, 66, 103-142. [CrossRef]

66. Leana, C.R.; Van Buren, H.J. Organizational social capital and employment practices. Acad. Manag. Rev. 1999, 24, 538-555. [CrossRef]

67. Lee, S.H.N.; Ha-Brookshire, J. The effect of ethical climate and employees' organizational citizenship behavior on U.S. fashion retail organizations' sustainability performance. Corp. Soc. Res. Environ. Manag. 2018, 25, 939-947. [CrossRef]

68. Lavelle, J.J. What motivates OCB? Insights from the volunteerism literature volunteerism and OCB: A functionalist approach other-oriented Functions. J. Organ. Behav. 2010, 31, 918-923. [CrossRef]

69. Sande, J.B.; Ghosh, M. Endogeneity in survey research. Int. J. Res. Mark. 2018, 35, 185-204. [CrossRef]

70. Li, F. Endogeneity in CEO power: A survey and experiment. Invest. Anal. J. 2016, 45, 149-162. [CrossRef]

71. Scott, C.; Dool, R.; Mancini, D. The effect of paid time off for volunteerism on organizational citizenship behavior: Is it influenced by national culture. Int. J. Bus. Public Adm. 2018, 15, 52-71.

72. Carlo, G.; Okun, M.A.; Knight, G.; de Guzman, M.R.T. The interplay of traits and motives on volunteering: Agreeableness, extraversion and prosocial value motivation. Pers. Individ. Differ. 2005, 38, 1293-1305. [CrossRef]

73. Smith, D.H. Determinants of voluntary association participation and volunteering: A literature review. Nonprofit Volunt. Sect. Q. 1994, 23, 243-263. [CrossRef]

74. Bono, J.E.; Judge, T.A. Core self-evaluations: A review of the trait and its role in job satisfaction and job performance. Eur. J. Pers. 2003, 17, S5-S18. [CrossRef]

75. LePine, J.A.; Van Dyne, L. Voice and cooperative behavior as contrasting forms of contextual performance: Evidence of differential relationships with big five personality characteristics and cognitive ability. J. Appl. Psychol. 2001, 86, 326-336. [CrossRef] [PubMed]

76. Dang, C.; Li, Z.; Yang, C. Measuring firm size in empirical corporate finance. J. Bank. Financ. 2018, 86, 159-176. [CrossRef] 